\title{
Political Marketing Activity in Simultaneous Regional Elections 2015
}

\author{
${ }^{1}$ AMA SUYANTO, 2 RUNIK MACHFIROH \\ ${ }^{1}$ Faculty of Management Telkom University,Bandung, West Java, Indonesia, ${ }^{2}$ Department of Visual Communica- \\ tion Design, School of Creative Industries, Telkom University, Bandung, West Java, Indonesia.

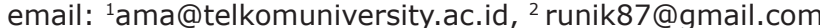

\begin{abstract}
Regional head election system was changed in 2015. It has impact on political marketing strategy to all stakeholders, such as political party and candidatures.The purposes of this research is to analyzeashifting ofpolitical marketing issueson regional election 2015. The research approach uses the mix method with the type of sequential explanatory. The subjects of this research are the candidates, election successful teams or supporting team, and young voters. Location of research based on cluster system district and sub district in Bandung, Cianjur, Magelang, Sleman, and Medan. The data are collected through techniques of questionnaires to young voters; interview to candidates, election successful teams and young voters, as well as the documentation of media and data on Regional General Elections Commission (KPUD). There are also triangular data techniqueinterviews with the General Elections Commission (KPU), the community and supporting team, and documentation and questionnaire form. The result shows that the system of political marketing has already started shifting from product, promotion, price, place, and people known as the 5Ps from mostly dominated by Political Partyinto the role of PEOPLE as candidature in influensing the voters. The Result also tells that shifting from using convetional media into almost using digital media was powerfull.
\end{abstract}

Keywords: marketing politics, regional election, Political Parties

\section{Introduction}

Indonesia as an archipelago country consisting of 13,466 islands with 34 provinces is divided into 416 districts and 96 cities that have their own local governance/autonomy system. As a country with democratic autonomy system of government, conducting the election of regional head/local leader is a realization of democratic character. The year of 2015 was the first time for Indonesia to execute the new form of the regional head election simultaneously. Regional election 2015 was different compared to the previous elections. Pangemanan (2013) says marketing played a role in 2015 regional head election, either directly or indirectly. Marketing as a part of management can be applied in practical politics in order to appropriately determine promotion strategies for both candidates of political parties or independent ones.
In 2015 regional election, there are 16 regional cities or districts which implement simultaneous regional election. The problems facing on the regional election in 2015 were mostly different with previous one, and so did with political marketing strategy that have been used. This election of 2015, which was done directly and simultaneously with the heterogeneous condition of Indonesia, was a challenge for the candidates to get many sympathizer/followers from constituents. Simultaneous regional election 2015 has a wide range of political marketing strategy's pattern in urban areas throughout Indonesia. On the regional head election before 2015, there were no rules about the simultaneous regional election. Research results by Pangemanan (2013) showed the regional head election in Bitung by 2010 reached an optimum result by applying marketing strategy of two way communication. With a different electoral system, this study wants to

Received: October 31, 2016, Revision: April 13, 2017, Accepted: May 19, 2017

Print ISSN: 0215-8175; Online ISSN: 2303-2499. Doi:

Accredited by DIKTI. SK Kemendikbud, No.040/P/2014, valid 18-02-2014 until 18-02-2019, Indexed by DOAJ 
mapping a shifting after political marketing is used in regional head election of 2015, based on the information from Election Supervisory Agency (Banwaslu) on Tempo (2016). The information said that cases of electoral fraud increased compared to last year election. Simultaneous regional election system applied with the aim to squize the electoral fraud. It is important to study a political marketing strategy without reducing the essence of democracy and intended to reduce fraud.

This study has difference result with previous ones. Kunkurat (2005) who just saw the political marketing in 2004 elections through television, then Suryadi (2006; 2008) studied direct presidential election in West Java with the main focus on political communication of independent candidates; Suyanto et. al (2014a) on political marketing at legislative elections in West Java; also Suyanto et. al (2016b) reviews on how digital media affects beginners voters. This study focuses on mapping the political marketing strategy used by candidates of regional head election in 2015, either those from political parties or independent. This study also describes the shifting of political marketing occurred in order to identify things that would lead to fraud at the campaign. The result can be used as a preference for the next regional head election using direct and simultaneous system.

\section{Research Methodology}

The approach used in this research is a mix method with the type of sequential explanatory. This study is more to quantitative with in-depth qualitative through survey methods. The source of the data acquired from young voters, interviews with candidates, successful teams or supporting team, and novice voters. The location of this study based on cluster system districts and sub districts in Java particularly West Java (Bandung, Cianjur), Central Java (Magelang, Sleman) and one city in North Sumatra, Medan. Total respondents is 400 people with the selection respondent's using theory of Slovin. Data collection techniques using questionnaire addressed to young voters; interview with candidates, successful teams and young voters and documentation from the media as well as data from Regional General Elections Commission (KPUD). Validity and reliability of data obtained statistically. In addition, triangular technique is carried out by doing interviews with the General Elections Commission (KPU), the community and success team; and also, data from documentation and the results of questionnaires. The data is being analyzed by using qualitative and descriptive inferential techniques to deepen the analysis of the data.

\section{The Shift in Marketing Strategy of Simultaneous Regional Election 2015}

The regional head election in 2015 with simultaneous and direct system is considered as one of the prerequisites embody of democracy. In a democracy, the participation is not only a form to defend the interests, but rather is a public process which does not claim a truth beyond what was adopted in consensus by citizens. According to Faulk (2010:257), "An effective democracy is a system that shows a combination of greater citizen engagement, such as the Council of citizens and the referendum, proportional representative bodies and reliable in the context of the Constitution which defend human rights and realize the various types and levels of political participation". Participation is seen as the involvement of citizens in the political process which is not limited to a sense of belonging as a part of the political system, but also with regard to the system of participation that accommodate the participation of citizens in the political process taking place. However, Giddens (2002) states that democracy is currently experiencing a threat of being undemocratic and need for reconstruction. In addition, based on data from Election Supervisory Agency (Bawaslu, ) election fraud for the regional head election in 2015 have elevated, then Suryadi (2008b:6) states that the political efficacy of citizens/ voters' decision will emerge when it causes an impact to the change of the political system. It means that mapping and analysis of political marketing of regional head election in 2015 need in-depth study in order to enhance the participation of citizens in decision making as well as effective strategies for a candidate so as to prevent a fraud during the process of election.

There were 217 elections of regional head, either in district or cities in 2015. Based on data from General Elections Commission (KPU) in 2015, simultaneous regional head election took the winners (76\%) from political parties (source: pilkada2015.kpu. go.id accessed on December 30, 2015). It means that the political party has a function as a liaison between the people and the Government. Therefore, the discussion of the results of this study will explore the mapping 
activity of marketing politics thoroughly and identify things that can lead to a tendency of cheating or fraud inpolitics at the results of the analysis of each activity on the regional head election in 2015. The finding of this research is that people are one of the factors in political marketing, which in contrast to the findings of some research by Pangemanan (2013), Kunkurat (2005), Suyanto et.al (2014a) which excluded 'people' from the list of indications in political marketing discussion.

\section{The Shifting of "Product" in Political Marketing of Regional Election 2015}

Political product is the programs and the vision offered by the candidates or their supporting political parties to their constituents. Political marketing strategy is needed because consumers can take the decision to buy a particular product (Suyanto, 2015c) and this is a sub indicator of product indicators in this study. In accordance with research of Endang (2012) which said that product in the marketing of politics is a platform of political parties that form the concept. Wheres in other researchers, figures and characteristics of candidates is part of a product as it is shown in the researchers of Firmazah, (2012); Suyanto et.al (2014a), Kunkurat (2005), and Pangemanan (2013). Whereas this research put candidates' personal in "person" or "people" finding instead of "product" related to the regional head election of 2015. "product" of politics has slightly shifted in simultaneous regional election. In previous elections, the products offered in the form of programs which are less measurable. It is in accordance with the research results of Suyanto et. al (2014a) who mapping the political marketing at the legislative election. However, in simultaneous regional election in 2015 related to products offered (such as programs), most of the candidates or political parties have performed a mapping (prior research) by doing a "hands-on operation" or "blusukan (in Bahasa)". This is in accordance with research by Sutanto (2014) which stated that "hands-on operation" (blusukan) has become an icon of one of the candidates' marketing product in the last Presidential Election in 2014. In Regional head election of 2015 " hands-on operation " became an important point in the political marketing for responses to constituents. However, the" hands-on operation" has turned into the euphoria from each candidate. They offered almost similarities programs such as free education, free healthcare, provide the park or green space to community, etc. But according to research by Kunkurat (2005), and Pangemanan (2013), which showed that the similarities between the candidates in the program will form a less effective political positioning, which means that the distinction of each candidate became an important factor in shaping an effective political positioning. However, some candidates or parties were still offering such programs. Taking further analyze, the making of gardens or parks is one of the success examples of Bandung Mayor in providing green spaces in Bandung. But not all areas require the creation of new parks/ green spaces. Regional District/sub district was different from the city, because they have already had their own natural parks, then the program offered should be a revitalization of natural parks by utilizing existing resources.

However, if it viewed from the influence of the voters' decision, it is found out that the dimensions of the product from the candidates of the political party have greater power than the independent ones which respectively has a count of $78 \%$ and $70 \%$. It mean that the power of the party have an influence in the simultaneous regional election of 2015 . The largest percentage of the candidates carried out by political parties based on capacity/ capability/competency, i.e. as much as 100\% and the smallest is located on the image/ popularity of political parties i.e. as much as $38 \%$. In addition, it turned out that private rights issues currently shifted into public rights were associated with space of comfort, confidence, and satisfaction of society due to the similarity of religion, culture, or race/tribe of the candidates, which amounts to $51 \%$. Thus, the heterogeneous in Indonesia is still basing on the similarity of religion, culture, or race/tribe. It should become vigilance from various candidates or supporting parties to remain cautious to related issues. These issues need to look out in order to avoid violation occurs at campaign time.

\section{The Shifting of Political Marketing "promotion" in 2015}

Based on the results of data analysis, the use of media marketing politics has undergone a shift in the simultaneous regional head election in Indonesia. The shift is from the conventional to the digital. Media marketing politics in earlier era still used print media, such as pamphlets, billboards, and banners. Research result by Suryadi (2008b) showed that the media campaign of a political party was only number and 
symbol of political parties. This means that the conventional media such as billboards or banners are less effective in conveying a political product that contains values for citizens, especially to novice voters. On the simultaneous regional election 2015, based on the results of research, the media promotion is dominated by digital media but still coupled with the conventional one. The strategy that widely being used by the candidate is ' hands-on operation "i.e. the candidates and their supporting political parties make a visit to the citizen or community or do the "direct selling". In addition, the visit should involve public figures to reach of $89 \%$ effective. Butler and Collins (2001) state that the promotion is permanent aspects of politics that should be done by a political party, politician, or a contestant in building trust and public image. Then these will keep in mind until the time for the general election arrives (Arifin, 2014). That is to say in the simultaneous regional election 2015, every candidate put their special promotion using digital technology and "hands-on operation". Reinforced by Firmanzah (2012), that Indonesia's current political phenomenon is still followed by the issues of the technological development or digital era. However, the current media, particularly digital, became a major factor to look out for by various political parties to anticipate fraud. Although based on rules, which is the regulation no 14 of 2014, each candidate may only register one account of social media. But, the fact is, one candidate has multiple accounts in social media. This should be a concern of Election Supervisory Agency and Regional General Elections Commission (KPUD) that currently, with the shift of media promotion used, required a rule that can track the activity of social media. According to research by Littlejohn (2009:454) showed that the current two steps in media effect influenced the interpersonal communication which found that media has become a great power in the election. It is also mean that the media promotion is indeed an important factor in political marketing. It turns out that the propaganda through the media could become an interesting topic of elections in many different countries. Propaganda is the interesting choice because it is expected to increase the popularity of a candidate or a political party. Social media in the digital era became one of the effective and efficient media for promotion. However, social media is highly susceptible to use for political propaganda. Considering that current internet users of social media in Indonesia has already reached $50 \%$ of the the population (APJII, 2016). Social media or television becomes a special study on how the supervision and restriction applied to the contents uploaded. In contrast to the results of the research of Sutanto (2014) which stated that propaganda in the presidential election is in the form of testimonials. In the simultaneous regional election of 2015, not only the testimony but life of the candidate was also become the content of propaganda, which carried out by political opponents and the buzzer in the virtual world or social media.

Based on this research, regarding the dimension of promotion used by a candidate of local leader, $82 \%$ of respondents stated that they chose the candidates based on the effectiveness of the promotion they have done, and $18 \%$ of the choice is not affected by the promotion. The highest percentage $(100 \%)$ of the candidates lied on the use of electronic media as introducing tools of the candidates through the use of banners, billboards, brochures, pamphlets, leaflets, and others as a media campaign, and a visit/ hands-on operation with citizens. The smallest percentage of the local leaders' candidates is in the aspect of popularity of political parties $(38 \%)$. The above data showed that the popularity of political parties take a slight effect on the decision of the electorate, meaning that propaganda through the media to increase the popularity of a candidate or a political party is not required. Social media is best used as a promotion media of a product or programs and activities conducted for the community, regarding that social media in Indonesia has become one of the great powers for the promotion. This became the shifting point which distinguished regional election now and then. Although conventional promotion is still in use, it is only limited as to introduce the faces and slogans of candidates and their political parties.

\section{The Shifting of Political Marketing "place" of Regional Election 2015}

On the regional election 2015, post of command or the winning place still contributes a victory to a candidate or political party which in accordance with the results of previous research by Firmazah (2012); Suyanto.et.al (2014a), Kunkurat (2005), Pangemanan (2013) Sutanto (2014). The location (place) is closely associated with the way of existence or location of distribution of a party and its ability to communicate with voters. This means that a political party for a candidate should really 
understand the key point of distribution, locations and strategic messages to be able to map the structure and characteristics of the community, either geographically or demographically.

All the respondents of this research stated that one of the indicators in the dimension of the place is related to ownership and the site selection to place attributes of the campaign, such as flags, banners, billboards, and others which contributed in improving the decision-making of the voters. In addition, the location of the Secretariat (posko) and the accessibility close to the area or base of the constituent contributes in boosting the animo of the voters due to the proximity of constituents to the political party.

Different conditions occurred to independent candidates, where their dimension of the place gives less contribution in boosting voters' decision. The independent candidate does not have a permanent secretariat or winning post (place) which consistently becomes the location of political activity. The winning Secretariat appears only when the candidate submits for and during the election, and disappears prior to and/or after the election, whether they win or loose. In addition, the spread of political attributes such as billboards, banners, flags, and others which became information media of candidates are limited, due to the limited power of supporting candidates themselves and/or volunteers.

In contrast to the explanation above, the candidates carried out by political parties have everything in need to gain power and party's support related to funding resources. They also automatically have the support of the masses which ideologically bound with a party or which Nimmo (2010) termed as the reactive type of voters, that is, the figure of voters who have an emotional interest with a political party that became the main source of action and voter. In this context, it isn't really a party attributes and location which become a key point, but rather at how far a location/command post of political party is located. The shift in media promotion has also shifted "place" in the simultaneous regional election in 2015. A slogan or program must be strategically placed in the right online sites and social media. In addition to placement, time will also affect. Displaying the same content too often would bored people. However, in digital media, candidates or political parties should already be able to recruit people to become I.T. and work in media center. It means that the candidate or the party should have an attractive website which contains (at least) shining profiles of the candidates, vision, mission, and work programs offered. Testimonials from significant people support as the amplifier, the activities carried out prior to and at the moment of the campaign. The media coverage in the form of photographs and phrases from candidates related to problems in the community, as well as the integration of social media. Attention should also be paid to the content of the website. Based on the results of this research, it turns out that any candidate who utilize digital media needs more than just a website maker, but also requires the design team, content (with strong knowledge on vision, mission, and work programs) and the buzzer to revive and promote the product. Therefore, the great programs with their vision and mission require amplifiers in a suitable place to run effectively. This contrasts with the results of the research by Suryadi (2006a) which said that a political party in the presidential election in West Java has a billboard only for a slogan of political party placed at the intersection. That is the shift/change which differentiate regional election in 2015 with the previous ones. The tendency of the "place" will be more likely on digital media rather than on conventional. Previous studies stating that the placement of billboards and banners may partly disrupt the aesthetics and damaging the environment. That is, the placement of the billboard on the streets, as well as on the trees, which turned out to disturb the beauty and add the work to securities who should take the billboard out when the campaign ends. While for the online, when the campaign ends, websites and sites used by the candidates and parties are simply disabled by Regional General Elections Commission, General Elections Commission, Election Supervisory Agency in compromise when the time of campaign ends.

\section{The Shifting of Political Marketing "price" of Regional Election 2015}

On the simultaneous regional election 2015, "price" dimension that is used to analyze the candidates include; funds/cost required as well as the magnitude amount of the private wealth owned by a candidate in order to win the election. This is in accordance with previous studies conducted by Firmazah, (2012); Suyanto.et.al (2014a), Kunkurat (2005), Pangemanan (2013) Sutanto (2014). The research result by Saputra et.al (2014) 
stated that in the campaign, one of the candidate couples of Abah Anton and Sutiaji have spent about 10 billion for the physical cost to promote programs and also psychological costs. However, at the simultaneous regional election in 2015, a larger price was dominated by the candidate of political party, amounting to $78 \%$, while for independent candidate is only about $70 \%$. In addition, the incumbent has also a big factor in the price.

The percentage of candidates who carried out by political parties or independent based on the cost required with respective percentage is $100 \%$ and $70 \%$. On the other hand, as many as $56 \%$ (carried out by political party) and $64 \%$ (independent) see that the magnitude of the fund/cost owned by candidates of a local leader provides great opportunities for them to win the election, as there is no straight definition yet of the difference between cost politic or money politic. This is in accordance with the results of Arwiyah (2012) who stated that in field reality at the time of the regional election, there were vague in distinguishing cost politic and money politic. This is the point to be concerned for all the elements to avoid cheating or money politics in election. The research result by Yani et.al (2008), showed that the public prefers the open campaign and received pocket money of Rp 50,000-Rp 100,000 every time they follow the campaign. This is something to look out for.

Based on an analysis of each indicator of marketing politics before, that a shift has happened in political marketing at the simultaneous regional election in 2015. It is also necessary to be cautious at a shift related to "price". The shift is happening on a point of political products offered to the public which is more to popularity rather than ideology. Therefore, the prospective candidates are the popular persons known by the public and it is no longer based on the candidates' ability in understanding and have skills in governing. It means that the price issue also underwent a shift.

Currently, Indonesian people have already begun to reject the existence of a "dowry" politics. It means reducing the cost politics of the candidate's. However, in contrast to the opinion of Markoff (2002: 206), which indicating that the phenomenon of money politics is the hybrid transition period to democracy as Indonesian. Therefore, based on the results of this research, digital media as a center of political marketing is needed to make an efficient and effective political campaign. However, there must be an official list of buzzers used by candidates and rules related to the management of the buzzer since the buzzer team recruitment also cost quite money.

\section{The Shifting of Political Marketing "people" the Regional Election 2015}

The dimension of 'people' is used in simultaneous regional election of 2015 to analyze candidates who carried out by political parties or from independent, including; the figure of the candidate, the involvement of public figures/community leaders in the campaign, as well as determined based on its position as the incumbent. Viewed from the "people" side, a candidate that carried out by political party seems lower than independent candidates. This is contrasts to previous studies which categorized "people" into "product" as it is stated by Firmazah, (2012); Suyanto et.al (2014a), Kunkurat (2005), Pangemanan (2013), Sutanto (2014). The researchers separated a variable of "people" because it has its own sub indicators which influential, and therefore, needs a further and in-depth study.

The percentage of candidates which are carried out by political parties viewed from dimension of "people" are $73 \%$ with the highest percentage on the involvement of public figures on political campaigns amounted to $84 \%$, and the remaining $67 \%$ is the figure and position of candidate from independent. Whereas, for the independent candidates, figures and public involvement/support during the campaign gained percentage of much as $100 \%$, and $64 \%$ chose for his position as the incumbent. The popularity and figure of the candidates and supporters turned out to have a major effect in influencing voters to choose their options. Research by Mietzner (2009), stated a big leap for consolidation occurred in Indonesia so that a new party has nominated popular candidates. Nevertheless, all parties should be concerned that popularity need to be balanced with positive track record of the candidates as well as the ideology of the party. This is in accordance with the results of the research by Suyanto et.al (2014a) which said that popularity has a great influence on the legislative election victory. Based on the results of this research, analysis of the marketing mix in the election of the local leader can be seen as a step in the determination of political marketing strategy (marketing politics), particularly, the political 
positioning of the candidates and also to minimize the tendency of cheating in politics or fraud.

\begin{tabular}{|lcc|}
\hline \multicolumn{3}{|c|}{$\begin{array}{c}\text { Recapitulation of Data Analysis for Local } \\
\text { Leaders Political Marketing }\end{array}$} \\
\hline Dimension & $\begin{array}{c}\text { The candidate of } \\
\text { carried political } \\
\text { party }\end{array}$ & $\begin{array}{c}\text { Independent } \\
\text { candidate }\end{array}$ \\
Product & $74 \%$ & $73 \%$ \\
Price & $78 \%$ & $70 \%$ \\
Promotion & $82 \%$ & $82 \%$ \\
Place & $85 \%$ & $52 \%$ \\
People & $73 \%$ & $88 \%$ \\
\hline
\end{tabular}

Source: the data processed by a team of Researchers (2016)

Based on the data presented above, it can be concluded that the largest marketing dimension for candidates carried out by political party is "place", and the smallest one is "people". Whereas, for independent candidates, the largest percentage is "people" and the smallest is "place".

\section{Conclusions}

Political marketing activity in the simultaneous regional election of 2015 is slightly shifting from the one who gets the greatest support from political parties into the role of the figure or people of the candidate's party. "People" or known as 5Ps is a new indicators of political marketing aspect found in this research. It means that "people" as candidates or people who are surrounding and behind the candidates have influenced the decisions of constituents/voters. The popularity of political parties only gives a slightly effect on the decision of the voters. Therefore, the propaganda through the media to increase the popularity of a candidate or a political party is no longer required.

Political product used by the candidates would not attractive to constituents if it is not supported by the "place". "Place" as a medium for political parties to promote political product has undergone a shift and replaced by digital media. Digital media used are social media, web and applications created for promoting products owned by the candidates. This shift has also an impact to the "price" that should be spent by candidates. Social media is best used as promotion media for products or programs offered as well as the activities performed for the community. Social media in Indonesia has become one of the great powers of promotion tool. Accordingly, a policy related to the utilization of digital media on marketing politics is needed. Shifting in political marketing occurred following the digital era, therefore, it is about the time to set a policy to regulate the use of e-marketing politics.

\section{References}

APJII. (2016). Laporan Survei tahun 2016 APJII.www.apjii.com

Arifin. A (2014). Politik Pencitraan Pencitraan Politik. Yogyakarta : Graha IImu

Arwiyah. (2012). Peranan Status Sosial Ekonomi dan Kualitas Partai Politik Pada PILKADA. Jurnal MIMBAR XXVIII No 1 (Juni 2012) 1-24.

Butler \& Collins. (2001). Strategi Pemasaran Politik. Jakarta. Media Grup.

Endang. (2012). Peran Pemasaran Politik Dalam Mempengaruhi Keputusan Pemilih. Jurnal Ekonom, Vol 15, No 4, Oktober 2012.

Giddens. (2002). The Third Way: The Renewal of Social Democracy. Edisi Bahasa Indonesia, berjudul "The Third Way: Jalan Ketiga PembaharuanDemokrasii Sosial". Penerjemah: Ketut Arya Mahardika. Cetakan ke-empat: 2002.

Faulk, K. (2010). Sosiologi Politik Pengantar Kritis. Bandung.Nusa Media.

Firmanzah. (2012). Marketing Politik Antara Pemahaman dan Realitas. Jakarta: Yayasan Obor Indonesia.

Kunkurat. (2005). Marketing Politik sebagai faktor Deteriminan dalam Pemilu 2004. Jurnal Westhpala Vol 13 no 1 Tahun 2004

Littlejohn, Stephen K. and Foss, Karen. 2009. Theories of Human Communication Ninth Edition. Jakarta. Salemba Humanika

Markoff, J. (2002), Gelombang Demokrasi Dunia, Gerakan Sosial dan Perubahan Politik, Yogyakarta: CCSS

Mietzner, M. (2009). Political opinion polling in post-authoritarian Indonesia Catalyst or obstacle to democratic consolidation, Bijdragen tot de Taal-, Land-en Volkenkunde, Vol. 165, no. 1 (2009), pp. 95-126, http:// www.kitlv-journals.nl/ index.php/btlv

Nimmo, D. (2010). Komunikasi Politik Khalayak dan Efek. Bandung: PT Remaja Rosdakarya

Pangemanan J.M.(2013). PEMASARAN POLITIK PADA PEMILUKADA (Suatu Studi Pemasaran Politik Pasangan Hanny Sondakh \& Maximilian Jonas Lomban, SE, M.Si Pada Pemilukada di Kota Bitung Tahun 2010). Jurnal Politico 
Saputra. (2014). Marketing Politik Pasangan Kepada Daerah Dalam Pemilukada (Studi Kasus Tim Sukses Pemenangan Pasangan Abah Anton dan Sutiaji dalam Pemilukada Kota Malang 2013). Jurnal Administrasi Publik (JAP), Vol. 2. No. 2. Hal 250-257.

Suryadi, K. (2008a). Pesan Politik di Ruang Publik: Pilihan-pilihan Sumber dan Media bagi Pendidikan Pemilih Vol 2 No.1. Bandung: iski.

Suryadi, K. (2006b). Pemilihan Presiden Secara Langsung di Jawa Barat: Implikasinya Bagi Pendidikan Pemilih, Jurnal Pendidikan "Mimbar Pendidikan" Nomor 3 Tahun XXV Tahun 2006, hal: 44-50.

Suyanto, AMA et.al. (2014a). Analysis of Political Marketing on Legislative Election. International Conference on Emerging Trends in Academic Research(Etar) 25 - 26November 2014). Etar(C)2014GlobalIlluminators, Bali, Indonesia.

Suyanto, AMA et.al. (2016b). Analysis of Political Marketing Activity On DecisionMaking For The District Leaders Election
To A Novice Voters. Internasional Journal IJIRES 6 November 2016.

Suyanto, AMA et.al. (2015c). The Influence of Lifestyles and Consumers Attitudes On Product Purchasing Decision Via Online Shopping In Indonesia. European Journal of Business and Management, 2015 Terbit 7 Vol 8

Sutanto HM. (2014). Propaganda Politik Calon Presiden Republik Indonesia 2014 -2019 (Analisis Isi Berita Kampanye Pemilihan Presiden Tahun 2014 Pada Harian Kompas Edisi 4 Juni Sampai 5 Juli 2014). Jurnal Humanity ISSN 0216-8995. Versi online / URL: http://ejournal.umm.ac.id/index. php/humanity/article/view/2391

Tempo. (2016). Kecurangan Pilkada 2015 Serentak Meningkat. 10 Januari 2016.

Yani, Ahmad, Sri Hayati, and Wahyu Eridiana (2008), Kajian Geografi Politik Terhadap Hasil Pemilihan Gubernur Jawa Barat (www.upi.edu)

www.pilkada2015.kpu.go.id accessed on December 30, 2015. 